\title{
CITRA DAN TANDA MALIOBORO DALAM KONSTRUKSI FOTOGRAFI
}

\author{
Edial Rusli \\ Dosen Jurusan Fotografi, Fakultas Seni Media Rekam, ISI Yogyakarta \\ Jalan Parangtritis Km 6,5 Bantul, Yogyakarta \\ No.Hp.+6285867299006,_E-mail: edial_rusli@yahoo.com
}

\begin{abstract}
Abstrak
Perkembangan zaman akan mengubah citra dan simbol Malioboro. Citra kawasan yang dulunya asri dan nyaman itu sekarang berubah menjadi semrawut dan tidak nyaman lagi. Keadaan ini menstimulasi ide penciptaan karya bahwa ruang publik Malioboro yang semrawut dan tidak nyaman itu dipersonifikasikan sebagai rumah besar yang ruang-ruangnya telah disekat-sekat layaknya kamar pribadi yang nyaman dengan kamar yang memiliki keunikan sendiri-sendiri. Konsep penciptaan dan perwujudan ini merupakan kumpulan objek imaji visual fotografi yang realistis untuk dikonstruksikan kembali dengan tujuan menghasilkan realitas imajiner. Pendekatan teori penciptaan ini adalah citra, konstruksi fotografi, dan makna. Proses eksperimentasi dan pembentukan karya diawali dari imaji-imaji visual fotografi yang dikumpulkan, diseleksi, dan direpresentasikan dengan citra objek kaum urban yang berjuang untuk hidup dan ruang cagar budaya yang terpinggirkan oleh bangunan modern di Malioboro melalui imaji visual fotografi. Imaji-imaji visual fotografi dari suatu realitas imaji masa lalu tersebut diimajinasikan ke masa yang akan datang untuk dikonstruksi kembali menjadi kesatuan dengan menggunakan teknik montase dan kolase digital imaging ke bentuk imajinasi visual fotografi yang imajinatif dan bernilai kreatif estetis untuk dimaknai kembali pada keadaan sekarang. Penciptaan karya ini tidak lagi berbicara tentang tataran teknis saja, namun juga berbicara tentang estetika, citra, tanda-tanda dan makna baru di dalamnya. Melalui penciptaan karya ini, masyarakat diharapkan dapat mengetahui citra, proses konstruksi, penyajian penciptaan karya, dan makna yang dihadirkan kembali dari perwujudan imaji ke bentuk karya imajinasi visual fotografi yang bernilai kreatif estetis. Karya imajinasi visual fotografi ini diharapkan menjadi media untuk mengungkapkan perasaan atau ekspresi dan emosi estetis pencipta dalam bentuk parodi visual. Penciptaan ini diharapkan dapat bermanfaat untuk memperkaya khazanah citra/imaji/makna baru dan untuk membangun rasa memiliki serta kesadaran akan permasalahan tata kehidupan dan tata ruang Malioboro sekarang ini.
\end{abstract}

Kata kunci: Malioboro, konstruksi imaji visual fotografi, estetika fotografi seni

\section{Abstract}

Image and Symbols of Malioboro in the Construction of Photography. Change of time will change the image and symbol of Malioboro. The image of this area that once was beautiful and comfortable now has changed into a chaotic and an uncomfortable one. This situation has stimulated an idea of creating artworks that the public space of Malioboro which is chaotic and uncomfortable is personified as a big house with separated rooms as in private bedrooms with their own uniqueness. The concept of the creation and the embodiment is a compilation of objects from photography visual images, which are realistic to be reconstructed with the aim of generating an imaginary reality. The approach for this creation is a photography construction's image and its meaning. The processes of experimentation and the formation of the works were started with the visual images of photography which were collected, selected, and represented with the images of urban people who struggle to live there and the cultural heritage which is marginalized by modern buildings in Malioboro through visual images of photography. Visual images of photography from the past reality of those images were imagined into the future time 
to be reconstructed as a unity by using techniques of montage and collage in digital imaging which would transform them into creative and aesthetic photography visual imagination to be reinterpreted in recent time. This creation does not only articulate the technique itself, but also to articulate the aesthetics, images, signs and new meanings in them. Through this creation, society is expected to know the images, the construction process, the presentation, and the meaning which are brought back from the visualization of images to the form of creative and aesthetic photography visual imagination. It is expected to be a media to express the artist's aesthetic feeling and emotion in the form of visual parody. This creation is expected to be beneficial in enriching the corpus of new images/meanings and to raise the sense of belonging as well as awareness of the problem of life order and the spatial layout of current Malioboro.

Keywords : Malioboro, construction of photography visual image, aesthetics of art photography

\section{PENDAHULUAN}

Fotografi sejak awal penemuannya adalah sebagai media imaji visual untuk merekam fenomena yang pernah terjadi dan sebagai media yang representatif untuk menghadirkan kembali realitas alam dan lingkungan dalam media fotografi. Dengan demikian, fotografi merupakan media untuk memindahkan jejak memori, merekam sekaligus merefleksikan realita, dan media representasi yang penting untuk mengabadikan suatu peristiwa yang telah berlangsung pada masa lalu, secara apa adanya dengan sangat sempurna.

Foto 1 merepresentasikan suasana ruasjalan Kawasan Malioboro pada tahun 1949 yang terlihat nyaman dan asri sebagai salah satu simbol historis Yogyakarta. Jalan ini mempunyai sejarah panjang akan ruang yang ditandai banyaknya bangunan bergaya arsitektur kolonial dan Tionghoa.

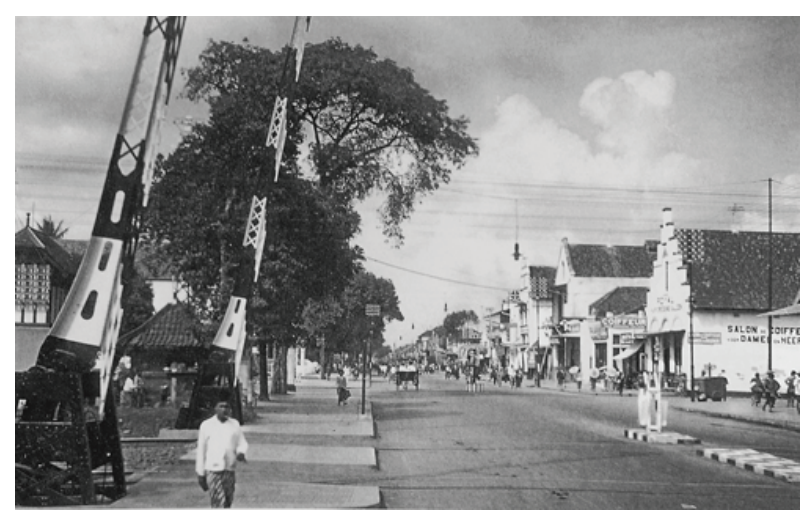

Foto 1. Jalan Malioboro

(Bruggen., Breukelen., et. Al., 1998:137)

SMG;1949; Foto hitam putih; Djokja en Solo, Beeld van de Vorstensteden; Asia Moir Purmerend, Netherland.
Evolusi zaman, pertambahan jumlah penduduk, dan pertambahan arus migrasi para kaum pendatang urban membuat Malioboro berubah menjadi kawasan yang menjanjikan bagi setiap orang untuk berbagai kegiatan sosial, budaya, dan perdagangan dari usaha kecil penduduk asli dan kaum pendatang urban dengan pola tradisional hingga usaha berskala besar yang berdasarkan prinsip kapitalis. Dampaknya, perbandingan antara luas kawasan dan populasi penduduk, serta aktivitas masyarakat menjadi tidak sebanding. Perluasan area dan pembangunan kawasan hanya bisa dilakukan dengan merekonstruksi secara fisik ke atas atau ke bawah. Beragam permasalahan tata ruang dan tata kehidupan lambat laun membuat kawasan ini menjauh dari keteraturan yang berakibat hilangnya keindahan kota, bahkan menimbulkan kesemrawutan, ketidaknyamanan, dan menyimpang dari citra yang dikumandangkan sebagai sebuah kawasan dengan slogan "Berhati Nyaman" (Bersih, Sehat, Indah, dan Nyaman).

Permasalahan tata ruang dan keberadaan kaum urban itu menjadi menarik untuk diamati, ditelusuri, dan diteliti untuk dijadikan penciptaan karya. Muara segala permasalahan tata ruang dan tata kehidupan bila dibiarkan berlarut-larut dan tidak kunjung selesai, akan sulit mewujudkan citra kawasan yang bersih, 
tertib, dan nyaman. Bahkan akan membuat citra kawasan yang telah dibentuk sebelumnya akan bergeser ke citra atau simbol yang baru sehingga orisinalitas Malioboro menjadi pudar. Terkait dengan segala permasalahan di atas bagaimana mengumpulkan dan menyeleksi kembali imaji visual fotografi untuk dijadikan citra dan tanda baru Malioboro untuk dikonstruksi kembali dan dimaknai dan dihadirkan kembali dari ke bentuk karya imajinasi visual fotografi yang bernilai kreatif dan estetis.

Karya ini telah mengubah fotografi sebagai media yang representatif yang merekam realitas secara sempurna dan objektif menjadi presentasi realitas imajiner berdasarkan imajinasi, ekspresi, dan subjektivitas pencipta dengan menggunakan media digital imaging fotografi. Karya ini juga diharapkan akan memunculkan citra dan penciptaan baru yang terbentuk bukan sekadar subjek foto dan bukan ungkapan kreatif yang estetis, melainkan juga makna baru dan sikap hidupnya yang peduli terhadap fenomena yang terjadi. Berdasarkan tulisan di atas, penciptaan karya foto ini berusaha untuk menelaah sejumlah hal, yaitu bergesernya citra Kawasan Malioboro, suatu upaya untuk mewujudkan citra baru tersebut dalam penciptaan karya imaji visual fotografi ke bentuk imajinasi visual fotografi, dan pesan atau makna yang dapat terbaca dalam karya ini.

\section{METODE PENCIPTAAN}

Sebelum pembahasan karya cipta ini terlebih dahulu akan dibahas timbulnya ide, konsep penciptaan, dan konsep perwujudan karya. Pengaruh latar belakang dan lingkungan sekitar penciptalah yang menjadi inspirasi terwujudnya ide penciptaan yang diungkapkan dalam penciptaan karya ini. Latar belakang, pengaruh lingkungan, dan pengalaman batin pencipta menginspirasi pencipta untuk melakukan perenungan, eksplorasi, dan pengamatan terhadap permasalahan tata kehidupan dan permasalahan tata ruang di Kawasan Malioboro. Permasalahan inilah yang menjadi latar belakang munculnya ide dan gagasan tentang manusia terutama kaum pendatang urban, ruang publik, benda, dan bangunan cagar budaya. Perubahan zaman membuat ruas jalan dan Kawasan Malioboro penuh permasalahan tata ruang dan tata kehidupan yang berdampak pada kemacetan lalu lintas jalan, semrawut, dan tidak nyaman lagi.

Dampak ini bila tidak disikapi dengan bijaksana oleh pemerintah kota, akan menyebabkan citra, simbol, dan identitas kota mulai bergeser dan lambat laun mulai pudar. Terlepas dari keberadaan kaum pendatang dan bangunan yang merusak kelestarian cagar budaya dan dianggap mencemari citra kota yang akan menimbulkan permasalahan kesemrawut-an dan ketidaknyamanan kawasan, ternyata permasalahan tersebut merupakan berkah bagi kaum pendatang urban untuk hidup nyaman di kawasan ini.

Inspirasi penciptaan karya ini tentang permasalahan tata kehidupan dan persoalan ruang di Malioboro, bahwa Malioboro yang semrawut dan tidak nyaman itu adalah kenyamanan Malioboro itu sendiri. Saat pelaku ruang melebihi kapasitas ruang yang disediakan, maka ruang semakin padat dan semakin tidak teratur yang menjadikan kawasan semrawut dan tidak nyaman lagi, namun ruang tersebut adalah kenyamanan bagi kaum pendatang urban.

Karya ini mempersepsikan ruang publik di ruas jalan dari Kawasan Malioboro sebagai sebuah rumah besar yang telah disekat-sekat layaknya ruang pribadi bagi kaum pendatang 
urban dan membagi ruang-ruang publik di kawasan tersebut layaknya ruang tamu, kamar tidur, ruang bekerja, kantor, ruang bermain, dan ruang-ruang lainnya. Ruang-ruang yang telah disekat menjadi ruang pribadi dalam suatu rumah besar tersebut bukan merupakan ruang yang realistis, melainkan ruang imajinasi dan ruang simbolik.

Ide dan gagasan ini diwujudkan dalam konsep perwujudan penciptaan karya imajinasi visual fotografi. Konsep perwujudan karya ini merupakan kumpulan dari imaji visual fotografi yang dikonstruksi kembali menjadi satu kesatuan karya imajinasi visual fotografi yang kreatif dan estetis dengan menggunakan teknologi digital imaging.

\section{LANDASAN TEORI}

\section{Imaji/Citra/Gambar}

Imaji senantiasa terkait dengan pengertian gambaran dan citra. Gambar merupakan tiruan benda hidup dan mati yang dibuat dengan lukisan, sedangkan gambaran merupakan hasil menggambar. Imaji adalah gambar, patung, kesan, dan bayang-bayang, sedangkan citra/image (Ing.) merupakan kesan batin/mental atau bayangan visual yang ditimbulkan dari objek figur dalam karya seni rupa. Citra sangat penting sebagai unsur yang turut berperan dalam karya karena membentuk ciri khas sendiri (Susanto, 2011).

Citraan merupakan cara membentuk citra mental pribadi atau gambaran sesuatu. Kris Budiman mendefinisikan citra/imaji/image sebagai tanda yang secara langsung bersifat ikonis, yang menampilkan kualitas-kualitas simpel seperti dapat dilihat pada gambar dan karya seni rupa pada umumnya (Budiman, 2011). Definisi citra/imaji/image fotografi menurut pencipta dapat disimpulkan sebagai bayangan/ilusi visual yang ditimbulkan oleh objek (ikonis berupa gambar, patung, kesan, dan bayang-bayang) untuk direpresentasikan kembali dalam karya.

Laksono, Broto, Irtanto, Riomandha, \& Gunawan (2000) membahas citra yang dibagi menjadi dua bagian, yaitu citra sebagai pengetahuan subjektif dan citra sebagai representasi. Perubahan citra dan identitas kawasan dalam penciptaan karya ini lebih menekankan pada citra subjektivitas dan representasi dalam bentuk imajinasi visual fotografi. Saat citra Malioboro sudah ditetapkan oleh Pemerintah Daerah Yogyakarta, citra tersebut menjadi citra yang mewakili Malioboro. Walau citra tersebut belum sesuai dengan realitas yang terjadi yang dikarenakan tidak memadainya informasi, pengetahuan, ataupun pemahaman yang dimiliki oleh kalangan masyarakat. Saat itulah penciptaan karya berusaha untuk mengimajinasikan citra kawasan berdasarkan subjektivitas pencipta. Kajian penciptaan karya ini berharap penemuan atau penciptaan citra baru yang direpresentasikan berdasarkan realitas yang terjadi ke dalam karya.

\section{Konstruksi Visual Fotografi}

Saat citra berubah, citra dan imaji sebelumnya dan pemaknaannya sudah bergeser menjadi citra dan pemaknaan baru. Karya ini merupakan suatu kumpulan imaji visual dari rekaman peristiwa realitas masa lalu melalui citra yang terepresentasi menjadi imaji visual permanen yang paling nyata yang nantinya dipresentasi pada masa sekarang dari imajinasi pencipta pada masa yang akan datang direkayasa melalui digital imaging menjadi imaji visual fotorafi yang realistis imajiner. Gabungan dari imaji-imaji visual fotografi 
yang bersifat dokumentatif sebagai alat bukti historis ini merupakan reproduksi simbol masa lalu yang direkam secara otentik melalui teknologi fotografi digital, yang dikonstruksi kembali menjadi satu kesatuan imaji visual dengan merekayasa menggunakan media digital imaging. Imaji ini merupakan manipulasi citraan dengan digital yang ekspresinya berdasarkan imajinasi dan subjektivitas pencipta untuk dipresentasi pada masa sekarang menjadi imajinasi visual fotografi yang kretif estetis. Dengan demikian, orisinalitas dan pemaknaan imaji-imaji visual sebelum dikonstruksi telah bergeser menjadi imaji, simbol, dan makna baru.

Proses konstruksi dalam penciptaan karya imajinasi visual fotografi ini menggunakan percampuran teknik kolase dan montase yang diolah dengan teknologi digital imaging. Penggunaan teknologi digital ini menjadikan solusi bagi seniman untuk lebih ekspresif dalam penciptaan karya seni fotografinya, yang selama ini menjadi kendala dalam karya fotografi konvensional. Proses penciptaan karya fotografi dengan mengolah secara digital ini memberikan kebebasan dan keleluasaan pencipta untuk mengonstruksi imaji berdasarkan keinginan pencipta untuk berekspresi.

\section{Tanda}

Karya imajinasi visual fotografi memiliki berbagai macam imaji dan tanda di dalamnya. Imaji dan tanda tersebut sebenarnya tidak mempunyai arti dan pemahaman sebagai makna, bila tidak pengkaji yang memaknainya. Semiotika adalah suatu model dari ilmu pengetahuan sosial di mana segala sesuatu yang ada di dunia dapat dipahami melalui tanda sehingga semiotika atau semiologi adalah ilmu yang mengkaji tanda (the science of signs).
Tanda merupakan sesuatu yang bersifat fisik, dapat dipersepsi melalui indera manusia dalam kehidupan manusia. Artinya, semua manusia yang hadir dalam kehidupan dilihat sebagai tanda, yakni yang harus diberi makna.

Ferdinand de Saussure yang menganut paham strukturalis melalui dikotomi sistem tanda: signified dan signifier atau signifie dan significant yang bersifat atomistis, melihat bahwa makna muncul ketika ada hubungan yang bersifat asosiasi antara yang ditandai (signified) dan yang menandai (signifier), atau kesatuan dan pertemuan antara penanda (signifiant) dan petanda (signifié). Penanda (signifiant) adalah imaji tanda seperti yang dipersepsi yang merupakan bentuk, sedangkan petanda (signified) adalah konsep mental yang diacukan petanda (signifié) yang merupakan makna atau isi.

Roland Barthes, penerus pemikiran Ferdinand de Saussure sebagai tokoh strukturalisme lebih dikenal dengan gagasan denotasi dan konotasi. Gagasannya ini dikenal dengan order of signification, mencakup denotasi adalah makna sebenarnya sesuai kamus dan konotasi adalah makna ganda yang lahir dari pengalaman kultural dan personal. Tingkatan pertama adalah denotasi, yaitu relasi antara penanda dengan petanda dalam sebuah tanda, serta tanda dengan acuan realitas eksternal. Tingkatan kedua adalah konotasi, yaitu menggambarkan interaksi yang terjadi tatkala tanda bertemu dengan perasaan atau emosi penggunaannya dan nilai-nilai kebudayaan. Mitos adalah tipe wicara dan sistem semiologi tataran kedua, di mana tanda pada tataran pertama menjadi penanda pada tataran kedua.

Menurut pencipta denotasi, bahwa setiap tanda selalu memperoleh pemaknaan 
awal (sesuai kamus/sistem primer) dan konotasi merupakan pengembangan dari tanda menjadi isi sebuah ekspresi yang didasari oleh kognisi dan pragmatik atau pemakai tanda dan situasi pemahamannya dan perasaan (sistem sekunder). Perbedaan antara denotatif dan konotatif dalam pengertian secara umum bahwa denotatif merupakan makna harfiah atau makna yang sesungguhnya, sedangkan konotatif adalah arti yang tidak sesungguhnya dan berbeda dari makna yang sesungguhnya.

Penciptaan karya fotografi terdapat dua tataran makna merupakan penggabungan antara apa yang terlihat secara nyata dan apa yang tersirat serta bagaimana cara mengemas makna tersebut dalam sebuah karya. Imajiimaji visual fotografi yang tampil merupakan tanda denotasi sekaligus penanda konotasi yang mengarah pada makna konotasinya. Barthes (2010); Budiman (2011); dan Sunardi (2004) merumuskan prosedur-prosedur untuk menghasilkan makna konotasi yang terdiri dari: (1) trick effect, misalnya dengan memanfaatkan teknik olah imaji secara digital; (2) pose, bisa dengan cara mengatur pose dan arah pandang objek yang dipotret; (3) object, misalnya melalui seleksi, penataan, dan pemilihan sudut pandang penciptaan; (4)fotogenia, yaitu dengan mengatur eksposur, lighting, dan sebagainya; (5) estetisme, dengan menerapkan teknik posterisasi; dan (6) sintaksis, yaitu dengan menampilkan beberapa foto sekaligus dalam bentuk sekuen sehingga penanda dan petanda konotasinya tidak dapat ditemukan korelasinya jika foto tersebut disajikan secara terpisah.

Teori konotasi Barthes menjadi tepat dengan kajian penciptaan karya ini, karena karya fotografi tidak hanya sebatas teknik, informasi, dan keindahan, namun sebuah imaji visual fotografi juga mampu membangun unsur pesan dan makna yang ada di baliknya. Makna penciptaan karya ini merupakan makna atau arti suatu kata yang berupa kiasan makna yang tidak sesungguhnya yang berdasarkan konsep dan subjektif si pencipta. Penciptaan karya imajinasi visual fotografi bukan lagi berbicara tentang tataran teknis yang membentuknya, namun juga berbicara tentang estetika, teori tentang tanda-tanda yang lebih global, dan pemahaman makna di dalamnya.

\section{PEMBAHASAN}

Pembahasan karya ini bertujuan untuk mengungkap citra, imaji, dan nilai-nilai baru dalam penciptaan karya yang kreatif estetis untuk diapresiasi dan dipahami makna yang terkandung dalamnya. Pembahasan karya Karyakarya ini tidak menggambarkan permasalahan tata ruang kawasan tata kehidupan di ruang publik Malioboro yang sebenarnya, tetapi karya ini merupakan imajinasi dan cara pandang pencipta untuk mengurai permasalahan ini.

Kawasan ini pada masa yang akan datang terimajinasikan dan tergambarkan dalam karya foto yang berjudul Rumah Malioboro, mengimajinasikan ruang publik yang tersekatsekat olehruang pribadi, karya foto yangberjudul Malioboro Tingkat Atas mengimajinasikan ruas jalan kawasan dengan pembangunan jembatan layang untuk mengurai permasalahan kesemrawut-an dan ketidaknyaman kawasan, dan karya foto yang berjudul Malioboro Bawah Tanah yang mengimajinasikan pembuatan bangunan bertingkat bawah tanah untuk mencari solusi akan pencemaran udara dan mengurai permasalahan pelestarian bangunan cagar budaya. Judul-judul karya ini merupakan salah satu cara mengurai permasalahan tata ruang yang terjadi di Kawasan Malioboro berdasarkan imajinasi pencipta. 


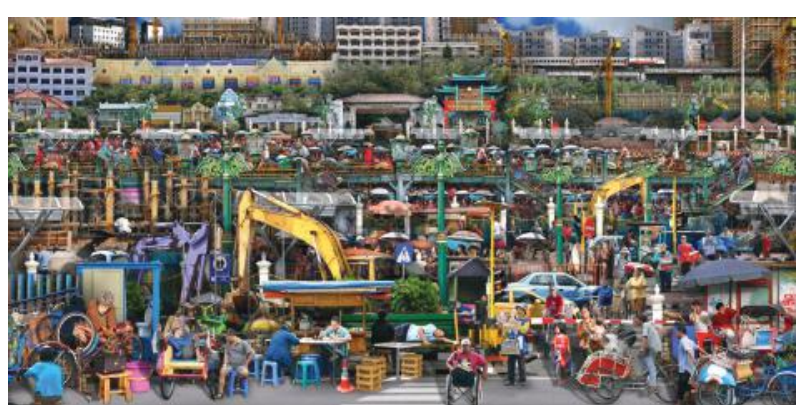

Foto 2. Rumah Malioboro (2017)

Edial Rusli; 2017; 230 x 115 cm; kanvas

Karya foto berwarna imajinasi visual fotografi yang berjudul Rumah Malioboro ini mengimajinasikan ruang publik Malioboro yang semrawut dan sudah tidak nyaman, yang dipersonifikasikan sebagai rumah besar bersama yang telah disekat-sekat layaknya ruang pribadi yang nyaman bagi kaum pendatang urban. Rumah Malioboro (2017, ukuran 230 x $115 \mathrm{~cm}$ dan bahan kanvas), dengan format horizontal dan jumlah imaji foto setiap karya sebanyak 293 bingkai foto. Subjek utama dalam perwujudan karya ini dipresentasikan sebagai sosok manusia yang berprofesi sebagai bengkel kendaraan tidak bermotor yang nyaman menggunakan fasilitas di ruang publik yang semrawut dan tidak nyaman. Subjek utama terlihat sedang memperbaiki sepeda dengan bantuan laptop sebagai alat bantu informasi dalam menyelesaikan pekerjaannya. Subjek utama bekerja di ruas jalan kawasan tanpa takut dirazia petugas pemerintah daerah (polisi dan polisi pamong praja), tertabrak kendaraan bermotor, dan segala risiko yang akan dihadapi. Ruang publik ini telah menjadi ruang bengkel reparasi kendaraan tidak bermotor sekaligus sebagai bengkel kehidupan baginya.

\section{Kenyamanan subjek utama} menggunakan ruang publik sebagai ruang pribadi terepresentasikan dalam bangku tempat duduk yang dipergunakan seperti tempat tidur (kamar tidur), angkringan seperti kamar makan, toilet umum seperti kamar mandi pribadi, fasilitas tempat duduk sebagai ruang tamu, dan lain sebagainya. Latar belakang karya memperlihatkan suasana kaum pendatang urban yang bekerja dalam proses pembangunan, peralatan angkat berat, berbagai aktivitas manusia dari berbagai lapisan masyarakat dengan ekspresi postural masing-masing, dan suasana kemacetan kendaraan bermotor.

Karya ini juga memperlihatkan jembatan layang untuk kereta api dan untuk kendaraan-kendaraan tidak bermotor (seperti sepeda, becak, dan becak bermotor). Pembuatan jembatan layang untuk kendaraan tidak bermotor ini untuk mengurai kemacetan lalu lintas dan kepadatan lalu lintas. Karya ini juga menampakkan bangunan-bangunan cagar budaya di Kawasan Malioboro yang mulai terhimpit oleh proses pembangunan gedung bertingkat dan bangunan modern terutama bangunan hotel berbintang.

Kawasan Malioboro ini memiliki permasalahan multikompleks, saat liburan tiba mulai muncul persoalan kemacetan kendaraan, parkir kendaraan, sarana wc umum, terbatasnya sarana air bersih, dan lain sebagainya. Walaupun pemerintah telah berusaha mengurai permasalahan dengan membuat kebijakan dengan pelebaran kawasan dan pembangunan jembatan layang untuk mengurai kemacetan lalulintas, kemacetan tetap saja terjadi. Agar kawasan ini tidak semrawut dan nyaman, diperlukan adanya penataan ruang yang terencana dengan didahului studi lintas disiplin yang mendalam. Kawasan ini mesti memiliki kebijakan dan instrumen yang ampuh yang harus ditaati semua pihak.

Penambahan perluasan area kawasan tergambar pada karya foto berwarna dalam Rumah Malioboro (2017) yang 
mengimajinasikan perluasan Kawasan Malioboro dengan memperluas area dan pembangunan secara fisik. Perluasan dan pembangunan ini bila tidak dibijaki secara baik akan berdampak pada permasalahan estetika kawasan yang secara perlahan menggeser pelestarian bangunan ruang cagar budaya, fisik kota, dan keaslian budaya.

Perluasan ini juga berdampak pada ruang-ruang yang sudah tersekat-sekat menjadi macet, berantakan, semrawut, dan tidak nyaman oleh berbagai aktivitas di dalamnya. Namun di sisi lain, semakin semrawut dan tidak nyaman kawasan tersebut merupakan ruang harapan hidup bagi mereka. Mereka tetap bersemangat untuk bertahan sebagai suatu langkah kelahiran baru untuk memasuki dunia baru untuk mendapatkan berkah dari Tuhan.

Dalam karya foto berwarna imajinasi visual fotografi yang berjudul Malioboro Tingkat Atas ini, pencipta mengimajinasikan ekspansi bangunan fisik yang menjulang ke atas untuk mengatasi terbatasnya luas area kawasan, mengurai kemacetan, ke-semrawutan, dan ketidaknyaman. Malioboro Tingkat Atas (2017, ukuran 345 x $115 \mathrm{~cm}$ dan bahan kanvas), berformat horizontal dan jumlah imaji foto setiap karya sebanyak 276 bingkai foto.

Profesi subjek utama adalah sebagai penjual endhog abang/telur merah. Gesture tubuh subjek utama yang duduk menikmati waktu istirahat dengan membawa ceret di tangan kanan dan sebuah gelas di kanan kiri.

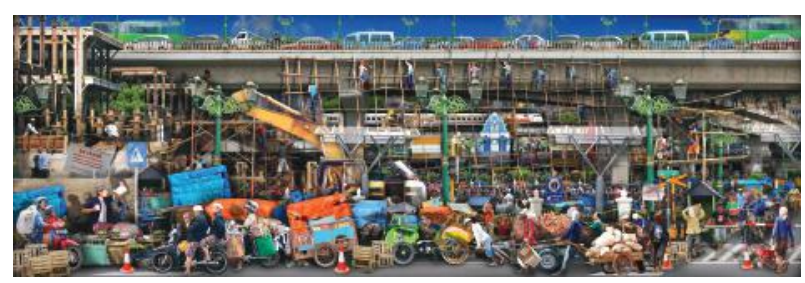

Gambar/Foto 3. Malioboro Tingkat Atas (2017)

Edial Rusli; 2017; 345 x 115 cm; kanvas
Ekspresi postural haus dan di belakang tampak kendaraan roda duanya yang digandengkan dengan gerobak dagangannya. Faktor pendukung subjek utama antara lain: seorang ibu naik motor dan anaknya membonceng di depan dan dua orang abdi dalem membeli endhog abang/telur merahnya duduk di atas sepeda motor. Fragmentasi potongan kehidupan ini memperlihatkan betapa kerasnya kehidupan dan tidak berdaya di tengah kerasnya tata kehidupan, namun mereka harus membanting tulang dalam hidup dan kehidupannya.

Latar belakang dari subjek utama tampak peralatan-peralatan angkat berat (crane, bego, dan beberapa alat berat lain), suasana aktivitas orang-orang dari berbagai lapisan masyarakat, suasana aktivitas kaum pendatang urban sebagai buruh bangunan yang sedang mengerjakan konstruksi pembangunan jalan layang, dan gedung bertingkat modern. Berbagai simbol tampak di Kawasan Malioboro, seperti bangunan cagar budaya Yuliana Apotheek (sekarang Indomaret), gedung perpustakaan negara (dulu penerbitan Kolf Bunning), lampu antik, baliho, becak Jogja, dan simbol lainnya.

Saat adanya kemudahan kredit kendaraan bermotor, masyarakat mulai mengonsumsi kendaraan tersebut sebagai solusi masalah transportasi. Kredit kendaraan bermotor semakin dipermudah dengan uang muka yang kecil dan biaya angsuran yang ringan. Saat kemudahan untuk mendapatkan kendaraan itulah memicu bertambahnya jumlah kendaraan yang akhirnya menyebabkan ke-semrawut-an dan ketidaknyaman. Walau keadaan ruas jalan itu macet, mereka tetap saja merasa nyaman dalam menjalani tatanan kehidupannya, bahkan memodifikasi kendaraan roda duanya dengan menambah gerobak di belakangnya. 
Karya ini memersepsikan dan mengimajinasikan pembangunan jembatan layang yang letaknya di tengah-tengah ruas jalan Malioboro untuk mengurai kemacetan lalu lintas kendaraan bermesin. Imaji ini mempresentasikan jembatan layang yang tetap terlihat suasana yang penuh sesak dengan kendaraan bermesin dan ruang publik sebagai ruang pedestrian tetap terlihat suasana semrawut dan tidak nyaman. Suasana ruang ini tetap menjadi ruang yang nyaman bagi subjek utama yang berprofesi sebagai menjual endhog abang/telur merah dan duduk menikmati waktu istirahatnya di ruang publik. Bila kebijakan pembangunan jalan layang tidak hati-hati justru akan menghilangkan Malioboro dan menenggelamkan bangunan cagar budaya. Dengan demikian, diperlukan solusi untuk mengatasi permasalahan tersebut dengan mengeluarkan peraturan dan kebijakan yang tepat dalam mengatasi permasalahan tersebut.

Penambahan bangunan fisik ke atas dan ke bawah untuk mengurai permasalahan Kawasan Malioboro ini terinspirasi kawasan metropolitan atau megapolitan yang terdapat di kota-kota besar luar negeri. Karya foto berwarna pada Foto 3. Malioboro Tingkat Atas (2017) mengimajinasikan wacana pembangunan jalan layang justru akan menenggelamkan bangunan heritage dan memperburuk pedestrian tata ruang Malioboro. Pembangunan secara fisik ke atas berdampak meningkatnya kadar polusi udara. Semakin banyak bangunan bertingkat tinggi yang dibangun menjulang ke atas, sirkulasi udara menjadi lemah dan berdampak keberadaan konsentrasi polutan akan bertahan lama. Makin banyak dan padatnya pembangunan fisik bertingkat ke atas berdampak pada berkurangnya vegetasi dan berkurangnya ruang hijau/terbuka yang berakibat peningkatan polusi udara, makin buruknya kualitas udara, dan meningkatnya suhu udara sehingga dapat membahayakan kehidupan masyarakat. Akibatnya, setiap saat masyarakat akan menghirup udara berkualitas buruk yang berakibat menurunnya kesehatan masyarakat pada masa kini maupun generasi yang akan datang.

Karya foto berwarna imajinasi visual fotografi yang berjudul Malioboro Tingkat Bawah ini mengimajinasikan kebijakan ekspansi bangunan fisik ruang bawah tanah mengatasi terbatasnya area kawasan, menjaga pelestarian gedung-gedung cagar budaya, mengurangi polusi udara, dan mengurai kemacetan, kesemrawut-an, dan ketidaknyamanan. Foto 4. Malioboro Bawah Tanah (2017, ukuran 115 x $230 \mathrm{~cm}$ dan bahan kanvas) dengan format vertikal dan jumlah imaji foto setiap karya sebanyak 322 bingkai foto.

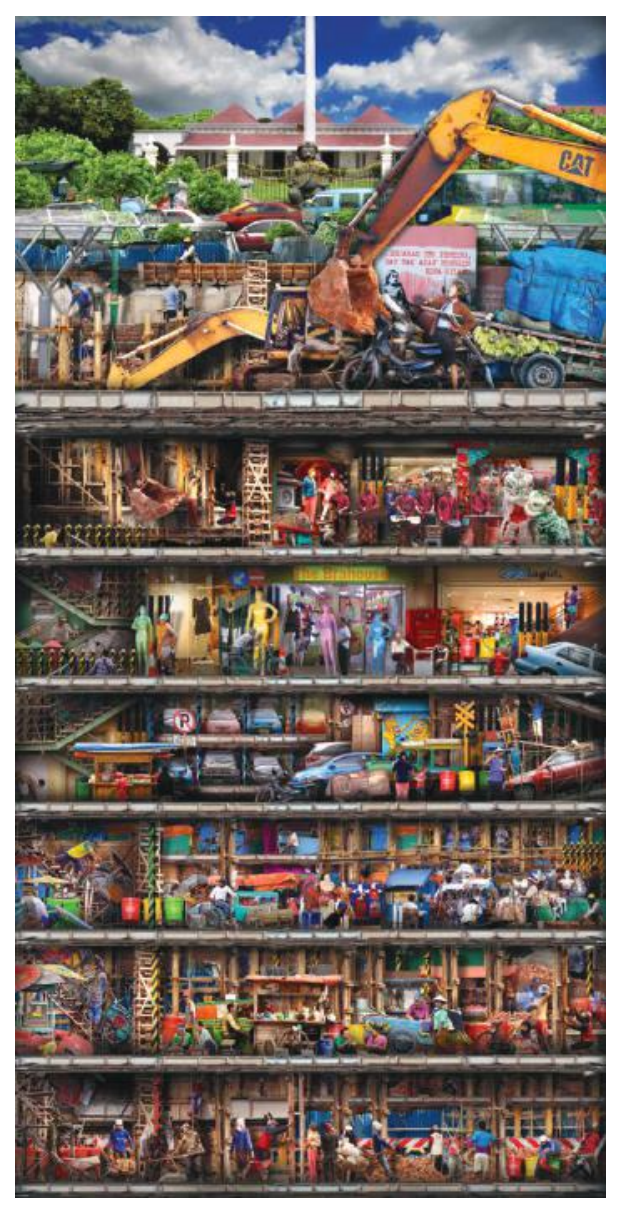

Foto 4. Malioboro Bawah Tanah (2017) Edial Rusli; 2017; 115 x 230 cm; kanvas 
Subjek utama tampak model lakilaki sedang menaiki kendaraan roda duanya yang dimodifikasi dan digandengkan dengan gerobak sebagai sarana transportasi. Subjek utama terlihat dengan gesture dan ekspresi postural terkejut saat melihat tangan bego yang kuat terlihat di depannya. Fragmentasi ini mengimajinasikan subjek utama yang tidak berdaya di tengah kerasnya kehidupan membuatnya harus mengikuti aturan dan kebijakan yang berlaku untuk direlokasi ke lantai empat bawah tanah.

Karya ini terbagi atas dua bagian yang menjadi subjek pendukung, yaitu bagian pembangunan atas tanah dan pembangunan bawah tanah. Subjek pendukung bagian bawah atau dua pertiga bagian dari seluruh format karya terletak di bawah, yang berupa gambaran imaji proses pembangunan bawah tanah. Pembagian ruang bawah tanah dari atas ke bawah adalah: (1) lantai satu bawah tanah: buruh bangunan, proses pembangunan bawah tanah, suasana berbagai pentas budaya dan pusat pertokoan modern; (2) lantai dua bawah tanah: buruh bangunan, proses pembangunan bawah tanah, dan suasana keramaian pusat pertokoan modern; (3) lantai tiga bawah tanah: buruh bangunan, proses pembangunan bawah tanah, dan suasana area parkir kendaraan bermotor; (4) lantai empat bawah tanah: buruh bangunan, proses pembangunan bawah tanah, dan suasana keramaian pedagang tradisional dan pedagang kaki lima, (5) lantai lima bawah tanah: buruh bangunan, proses pembangunan bawah tanah, dan suasana keramaian pedagang kuliner tradisional; (6) lantai enam bawah tanah: buruh bangunan dan proses pembangunan bawah tanah.

Pembagian lantai tergambar bahwa inovasi pembagian ruang berdasarkan strata. Lantai bagian atas untuk golongan strata yang memiliki modal besar dan semakin ke bawah untuk kaum pendatang urban dari golongan strata rendah. Dilihat dari sudut pandang pembagian strata ini terlihat bahwa golongan yang memiliki modal besar yang akan memberikan keuntungan bagi investor letaknya paling atas dan yang memberikan keuntungan lebih kecil letaknya lebih ke bawah. Karya ini menunjukkan bahwa mana yang akan diuntungkan dan yang dirugikan.

Sepertiga bagian atas menjelaskan keadaan Malioboro yang mempertahankan kawasan cagar budaya yang di dalamnyaterdapat subjek utama. Subjek pendukung bagian atas sangat bertolak belakang dengan bagian bawah yang mengubah Malioboro menjadi kawasan metropolis. Bagian di atas Malioboro terlihat humanis dengan kearifan lokal yang kental untuk mempertahankan cagar budayanya. Subjek utama terletak di bagian atas kanan dengan subjek pendukung di sekelilingnya, terdapat aktivitas pekerja bangunan yang sedang bekerja dalam proses pembangunan. Latar belakang subjek utama terlihat tembok pembatas yang di pintu besarnya bertuliskan "sejarah itu penting dan takkan mungkin dihilangkan". Tulisan tersebut difungsikan dan dikaitkan hubungannya dengan Gedung Agung sebagai gedung istana presiden dengan berbagai simbol khas Malioboro, seperti lampu antik, baliho, becak Jogja, dan lain sebagainya. Dengan kata lain, tulisan tersebut menjelaskan kebijakan pemerintah untuk selalu melestarikan Gedung Agung sebagai cagar budaya dan mengurangi polusi udara di Kawasan Malioboro. Dengan demikian, pembangunan bangunan bertingkat ke bawah merupakan solusi berbagai permasalahan tata ruang dan tata kehidupan di bagian atas. Karya ini mempresentasikan Kawasan Malioboro yang humanis dengan kearifan lokalnya yang 
tidak berubah, walau kawasan ini akan berubah menjadi metropolis.

Penambahan bangunan fisik ruang di bawah tanah tergambar pada karya berwarna dalam Foto 5. Malioboro Bawah Tanah (2017). Karya foto ini mengimajinasikan wacana penambahan bangunan fisik ruang bawah tanah ini merupakan salah satu solusi yang tidak berdampak pada tata ruang secara fisik seperti permasalahan estetika, penataan ruang kota, dan keaslian bangunan ruang cagar budaya dan fisik kota. Namun pembangunan secara fisik ruang bawah tanah berdampak meningkatnya kadar polusi air dan tanah. Pembangunan bangunan bertingkat ruang bawah tanah membutuhkan sirkulasi udara yang besar dan banyak sehingga dibutuhkan ruang terbuka di atas tanah dengan ruang hijau atau ruang terbuka yang berakibat peningkatan polusi udara. Bila tidak ada ruangan terbuka di bagian atas tanah, akan berdampak semakin buruknya kualitas udara serta meningkatnya suhu udara yang dapat membahayakan kehidupan masyarakat yang berada di ruang bawah tanah tersebut.

Bila dilihat dari beberapa sudut pandang, perluasan kawasan, jembatan layang, dan pembangunan bawah tanah akan mengubah Malioboro yang humanis dengan kearifan lokalnya menjadi metropolis. Di sisi lain pembangunan secara fisik ini dapat menciptakan peluang kerja, peluang kehidupan, dan mengurangi kepadatan di ruas jalan kawasan. Pembangunan tersebut membuka peluang kehidupan baru bagi pedagang makanan dan minuman dan dapat mengentaskan kemiskinan bagi para pedagang kaki lima, tukang bangunan, pekerja buruh kasar, mandor, dan lain sebagainya.

Subjek utama adalah model manusia yang menyimbolkan kaum pendatang urban. Identitas secara realitas kehidupan mereka dipandang tidak mempunyai kemampuan secara ekonomi, dianggap tidak sesuai dengan norma kehidupan kota, dan dianggap merusak citra kota. Identitas sosok mereka dikonstruksi kembali menjadi identitas imajiner yang disesuaikan dengan ide konsep dan imajinasi pencipta. Identitas imajiner merupakan sosok yang mapan secara ekonomi yang beradaptasi dengan norma kehidupan kota yang mendukung citra kota.

Sosok subjek utama yang dijadikan sebagai titik pusat perhatian dalam penciptaan karya ini tervisualisasikan dari identitas, tubuh, pakaian/aksesoris, profesi, dan posenya. Identitas imajiner kaum pendatang urban sebagai subjek utama diperankan oleh pencipta sendiri yang menggunakan topeng. Identitas topeng ini menampilkan wajah indo (kombinasi wajah tradisional dan modern) yang menyimbolkan identitas kemapanan, kenyamanan, keramahan, kesahajaan, dan keterbukaan. Gesture subjek utama terlihat seluruh tubuh dan tubuh lebih besar dibandingkan subjek manusia lainnya. Kostum dan aksesoris yang dikenakan untuk memperkuat identitas subjek utama adalah dengan wig berwarna putih, baju lengan panjang berwarna biru, berdasi, berjas warna coklat muda dan merah, mengenakan sarung, bercelana hitam petani, dan lain sebagainya

Subjek utama mereprentasikan profesi sosok kaum pendatang urban berfragmentasi berbagai profesi, seperti penjual angkringan, jamu, dan rokok. Pose dalam karya ini ditampilkan subjek utama yang sedang beraktivitas berdasarkan profesinya secara utuh dan arah pandang wajah model yang dipalingkan $45^{\circ}$ dan $90^{\circ}$ terhadap kamera. Ekspresi postural subjek utama yang dijadikan sebagai pusat perhatian yang menjadikan pembeda dengan realitas yang sebenarnya dan subjek yang lain 
tampak dari identitas, tubuh, pakaian/aksesoris, profesi, dan posenya untuk memunculkan kekontrasan, dinamis, dan kontradiktif.

Sudut pengambilan penciptaan karya dengan meletakkan garis horizontal (garis cakrawala) di atas atau sejajar dengan mata agar menampakkan keseluruhan unsur volume ruang, kedalaman, dan jarak antarsubjeknya. Walau perspektif dapat dikoreksi dengan digital imaging, pencipta berusaha untuk mengurangi cacat distorsi dan perspektif akibat pemakaian lensa yang tidak tepat.

Penciptaan karya ini menggunakan hukum perspektif (bahwa benda yang semakin jauh maka akan semakin mengecil dari pandangan mata). Walaupun tujuannya untuk merasakan unsur volume ruang, kedalaman, dan jarak antarobjeknya, tidak semua menggunakan hukum perspektif. Subjek utama tidak menggunakan hukum prespektif karena subjek utama terlihat lebih besar (distorsi) dibandingkan subjek pendukung lainnya.

Penciptaan karya ini menggunakan format sisi mendatar (horizontal) dan format sisi tegak (vertikal), sedangkan jumlah imaji dalam setiap karya imajinasi visual fotografi ini dapat dirinci sebagai berikut.

Seluruh bidang format diberi imaji foto penuh dan tidak ada bagian yang kosong. Penciptaan karya ini mengimajinasikan suasana Kawasan Malioboro yang penuh sesak, semrawut, dan tidak nyaman oleh aktivitas manusia dan pembangunan kawasan. Meski demikian, karya ini tetap menunjukkan dinamika ruang yang disusun dan dikomposisi secara harmonis dan enak untuk pandang.

Penciptaan karya ini menggunakan aturan segitiga (Rule of The Third), yaitu sesosok kaum pendatang urban (subjek utama) diletakkan di salah satu titik potong garis imajiner horizontal dan vertikal yang membagi imaji menjadi tiga bagian yang sama besar. Subjek utama tidak bisa berdiri sendiri dan selalu berhubungan dengan subjek pendukung utama dan gedung cagar budaya sebagai simbol keterangan tempat yang disusun ke dalam satu ruang (format) agar mencapai keutuhan, keseimbangan, dinamis, harmonis, serasi, dan proporsional.

Latar belakang dengan unsur garis/ bidang tegak (vertikal) tergambar dari tiangtiang lampu, proses pembangunan gedung bertingkat, gedung-gedung bertingkat modern, dan lain sebagainya dengan motif yang berulang akan membentuk pola tersebut akan memberikan kesan kekokohan, keagungan, kemegahan, dan kekuatan. Garis dan bidang datar (horizontal) tergambar dari jembatan layang, pagar, gedung-gedung cagar budaya dan lain sebagainya dengan motif berulang memanjang yang mengesankan keluasan dan kelegaan ruang.

Saat garis dan bidang vertikal, diagonal, dan horizontal dari objek-objek penciptaan ini dikomposisikan secara berulang-ulang, berdekatan, dan saling tumpang tindih, maka menampilkan ekspresi dan ungkapan pencipta untuk memunculkan kekontrasan, kedinamisan, kekontradiktifan, ke-semrawutan, dan ketidaknyaman. Garis-garis tersebut menampilkan permasalahan tata kehidupan dan tata ruang yang tidak nyaman dan semrawut oleh berbagai penuhnya aktivitas serta padat dan macetnya ruas jalan dengan aktivitas lalu lintas yang saling berlawanan, tumpang tindih, dan sangat rumit. Unsur-unsur ini juga merepresentasikan gedung cagar budaya yang semakin terancam dan terdesak oleh bangunan-bangunan modern yang lebih tinggi untuk memberi kesan ketidakberpihakan dan 
ketidakseimbangan antara bangunan cagar budaya yang terkesan tenggelam dan tersisih dengan bangunan perkantoran dan hotel modern yang menjulang tinggi.

Penciptaan karya ini memunculkan tingkat kerumitan dan ketidaksederhanaan. Kerumitan mempresentasikan visual, isi, dan makna yang saling berlawanan ataupun mengandung kekontrasan dan kerumitan permasalahan tata kehidupan kaum pendatang urban dan permasalahan tata ruang yang terjadi di Kawasan Malioboro. Walau memunculkan tingkat kerumitan yang tinggi, karya ini tidak melupakan unsur keseimbangan dalam mengomposisikan antara subjek utama dan subjek pendukung utama dengan latar depan dan latar belakangnya. Tiada keutuhan tanpa keseimbangan. Keseimbangan penciptaan karya ini menggunakan prinsip bahwa susunan ketidaksamaan dan ketidakseimbangan merupakan keseimbangan itu sendiri. Komposisi penciptaan karya ini adanya kesatuan yang utuh untuk dipresentasikan ketidakseimbangan antara subjek utama yang nyaman dengan latar belakang yang rumit, awut-awutan, berantakan, semrawut, dan tidak nyaman di Kawasan Malioboro.

Penciptaan karya ini adalah visual yang tercipta seolah-olah membawa penikmat ke ruang imajinatif, kelihatan bersekatsekat, tetapi terasa berada di ruang kawasan yang tanpa batas. Keunikan pembentukan dalam penggabungan beberapa imaji akan menampilkan penyimpangan-penyimpangan pada objek karena sebuah atau beberapa objek dapat terlihat dari sudut sisi lainnya. Tujuan dari penyimpangan bentuk ini adalah untuk melihat suatu objek tidak hanya dari apa yang dilihat, namun juga pada pesan yang tersembunyi dari objek tersebut.
Setiap karya diberi simbol imaji-imaji foto dari berbagai fenomena yang terjadi di kawasan ini sehingga setiap karya terlihat penuh dan ada beberapa bagian yang terulang. Keluasan bidang dua dimensionalnya dipenuhi dengan berbagai tanda, simbol, dan tidak ada ruang kosong. Penciptaan karya ini mengenal perspektif dan cakrawala, yang kadang-kadang menempatkan objek di bagian depan sama dengan bagian belakang objek manusia yang digambarkan dengan aktivitas masyarakat urban dengan latar belakang gedung cagar budaya.

Naluri ekspresi pencipta tersebut menghasilkan deformasi bentuk-bentuk objek bangunan dan sosok-sosok para pelaku yang saling tumpang tindih. Subjek utama dijadikan sebagai pusat perhatian (subjek utama) dalam menggunakan model manusia yang menggambarkan sosok kaum pendatang urban yang lebih besar dibandingkan dengan subjek pendukung manusia lainnya.

Pemilihan objek utama dan objekobjek pendukung dihadirkan secara kontras agar tampak ironi dari persoalan-persoalan yang akan diangkat melalui karya seni tersebut. Pembentukan latar belakang dan latar depan yang terkesan tumpang tindih tersebut memang sengaja dibentuk yang akhirnya merupakan identitas dan ciri khas pencipta. Proses konstruksi yang tumpang tindih tersebut mengindikasikan kesan yang semrawut, awutawutan, dan berantakan yang merupakan kesengajaan dari pencipta dalam penciptaan karya seni. Bentuk penciptaan karya imajinasi visual ini menggambarkan ironi bahkan suatu parodi dari permasalahan yang sedang terjadi di kawasan ini.

Kebaruan dari karya yang diciptakan ini terletak pada teknik penggarapannya, yaitu 
dengan menempatkan berbagai citra dan simbol objek dari fenomena yang terjadi di Kawasan Malioboro menjadi satu kesatuan. Penggarapan penciptaan karya ini untuk mengimajinasi dan mengaplikasikan ide-ide pencipta dengan menetapkan simbol imaji-imaji visual fotografi untuk dikonstruksi kembali dengan jalan eksplorasi dan eksperimentasi yang didasarkan pada imajinasi pencipta untuk menjadi suatu karya dari representasi realitas ke realitas imajiner pada masa yang akan datang dalam karya konstruksi fotografi.

Keunikan dari karya ini adalah visual yang tercipta seolah-olah membawa penikmat ke ruang imajinatif, kelihatan bersekatsekat, tetapi terasa berada di ruang kawasan yang tanpa batas. Keunikan dari setiap karya diberi simbol imaji-imaji visual fotografi dari berbagai fenomena yang terjadi di kawasan ini sehingga setiap karya terlihat penuh dan ada beberapa bagian yang terulang. Keluasan bidang dua dimensionalnya dipenuhi dengan berbagai simbol dan bentuk sehingga tidak ada ruang kosong. Kajian dan penciptaan karya ini tidak mengenal perspektif dan cakrawala, yang kadang-kadang menempatkan objek di bagian depan sama dengan bagian belakang. Objek manusia digambarkan dengan aktivitas masyarakat urban berlatar belakang proses pembangunan gedung bertingkat, gedung bertingkat, dan gedung cagar budaya di Kawasan Malioboro.

\section{SIMPULAN}

Karya-karya berikutnya mempresentasikan citra kaum pendatang urban sebagai wong cilik yang dianggap menjadi sumber permasalahan terjadinya ketidaknyamanan dan ke-semrawut-an tersebut. Namun, terlihat kaum pendatang urban menikmati ketidaknyamanan merupakan kenyamanan dan berkahnya ditinjau dari aspek gaya hidup, budaya, peraturan pemerintah, politik, dan ekonomi. Fenomena yang dimunculkan dalam penciptaan karya ini pada hakikatnya terkait erat dengan persoalan tradisi dan modernitas. Dengan kata lain, bahwa kaum pendatang urban sebagai pelaku ruang usaha tradisional tetap nyaman dan mampu bertahan hidup di antara kepungan pelaku usaha modern.

Penciptaan karya ini dengan pendekatan idiom parodi bertujuan untuk mengekspresikan perasaan ketidakpuasan dan ketidaknyaman terhadap kondisi sekarang. Karya-karya ini juga merupakan sebuah satir secara humoris sebagai suatu perenungan Kawasan Malioboro pada masa yang akan datang, yaitu Malioboro sebagai ruang sosial yang mengusung kearifan lokal dan tradisi atau Malioboro sebagai ruang urban yang mengedepankan modernitas untuk masyarakat urban.

Perubahan zaman ini juga akan memengaruhi perkembangan teknologi fotografi dari peralatan perekaman, proses perekaman, proses digital imaging, hingga media perwujudan karya. Perkembangan akan berdampak pada perubahan kreasi artistik dan estetis dalam proses dan perwujudan penciptaan karya fotografi. Perkembangan era digital sekarang ini bila tidak disikapi dengan bijaksana, maka peran seorang seniman foto menjaditidak hanya sekadarmerekam fenomena yang terjadi, namun dituntut kemampuan yang lebih dari praperekaman, perekaman, olah digital imaging, hingga proses perwujudannya. Hal yang menghambat dalam penciptaan karya adalah faktor cuaca, penentuan pencahayaan, dan waktu yang tepat dalam perekaman imaji agar tampak kombinasi temperatur warna (hue), nilai warna (value), 
intensitas warna (intensity), dan suhu warna yang sama. Saat proses konstruksi dibutuhkan stok yang banyak sehingga membutuhkan waktu yang lama dalam proses perekaman imaji dengan buru foto. Kemampuan media komputer saat proses konstruksi imajinasi visual fotografi yang terbatas membuat proses edting dengan menggunakan digital imaging lambat. Penciptaan karya ini menggunakan media cetak kanvas sehingga hasilnya tidak maksimal karena sisi terpendek terbatas maksimal 120 $\mathrm{cm}$ dan saat dicetak lebih besar bahan belum tersedia.

\section{KEPUSTAKAAN}

Barthes, R. (2010). Imaji/Music/Teks. Yogyakarta: Jala Sutra.

Budiman, K. (2011). Semiotika Visual; Konsep, Isue dan Problem Ikonitas. Yogyakarta: Jala Sutra.

Laksono, P., Broto, N. W., Irtanto, K., Riomandha, T., \& Gunawan. (2000). Permainan Tafsir: Politik Makna di Jalan pada Penghujung Orde Baru. Yogyakarta: Insist Press.

Sunardi, S. (2004). Semiotika Negativa. Yogyakarta: Kanal.

Susanto, M. (2011). Diksi Rupa, Kumpulan Istilah dan Gerakan Seni Rupa (Revisi). Yogyakarta: Penerbit Dickti Art Lab. 